PAULINA PERET-DRĄŻEWSKA

Uniwersytet im. Adama Mickiewicza

w Poznaniu

\title{
STYL ŻYCIA W CZASACH INDYWIDUALIZACJI. O WOLNYM WYBORZE JAKO KRYTERIUM DYFERENCJACJI SPOŁECZNEJ
}

\begin{abstract}
Peret-Drążewska Paulina, Styl życia w czasach indywidualizacji. O wolnym wyborze jako kryterium dyferencjacji społecznej [Lifestyle in Times of Individualization. Free Choice as a Criterion of Social Differentiation]. Studia Edukacyjne nr 32, 2014, Poznań 2014, pp. 63-77. Adam Mickiewicz University Press. ISBN 978-83-232-2837-0. ISSN 1233-6688
\end{abstract}

This article is a theoretical reflection on the changes of the quality of living "everyday life", a category of lifestyle, on the background of the socio-culturally based individualization. Apart form customization, another analyzed category of this study is the concept of a "lifestyle", the subject of interest of many scientific disciplines which highlight the different constitutive features. Today's conditions of postmodernity based on flexibility, change, a lack of stability and predictability, are not part of mainstream thinking about a lifestyle as a category closely-determined by external factors, even such as class membership. For considering the changes in individuals' daily lives, the subjective aspect should take into account internal factors, such as free will or choice. Consumerism is no doubt a contemporary trend which especially strongly changes postmodern societies, leading to changes in the quality of daily life of individuals. This area of human activity has become a defining force in a lifestyle, weakening the importance of class.

Key words: lifestyle, individualization, postmodernity, choice

\section{Wprowadzenie}

Współcześnie zachodzące przemiany społeczno-kulturowe nie pozostają bez znaczenia dla jakości przeżywania "codzienności” przez jednostki będące pod przemożnym wpływem takich trendów współczesności, jak: konsumpcjonizm, mediatyzacja, popkultura. Niniejsza refleksja, z pozoru trywialna i bezsprzeczna, wymaga podjęcia głębszych analiz i dokonania bardziej 
szczegółowych dookreśleń, bowiem pozwolą one wnikliwiej zrozumieć specyfikę powiązań jednostkowych, codziennych losów ludzkich z zaistniałymi warunkami społeczno-kulturowymi. W literaturze przedmiotu można odnaleźć wiele charakterystyk jakości współczesnych przemian, tak wieloznacznych ze względu na swoją naturę ambiwalencji i dychotomii. Rozważania nad ową jakością obecnie zachodzących przemian koncentrują się na odmiennych atrybutach określających istotę współczesnego społeczeństwa. W tym miejscu można przywołać takie kategorie operacjonalizujące zaistniałe warunki społeczno-kulturowe, jak chociażby: wielokulturowość, natychmiastowość, ryzyko, zmiana, informacja oraz wspomniane powyżej: popkultura, konsumpcjonizm, mediatyzacja. Podkreślę po raz kolejny, iż wymienione elementy składowe tworzące łącznie całe spektrum przemian społeczno-kulturowych nie pozostają bez znaczenia dla jednostkowej, codziennej egzystencji. Owe procesy niejako wymuszają indywidualne ustosunkowanie się jednostek $\mathrm{w}$ niniejszej kwestii, co rzutuje na zmianę ich relacji z szerszymi kręgami społecznymi, a co za tym idzie - zmianę podejścia wobec konstrukcji własnego projektu życia. Dla wyjaśnienia owych powiązań niezwykle trafne i pomocne okazuje się zastosowanie kategorii „indywidualizacja”, do której zawężone zostało pole problemowe niniejszej narracji. Artykuł ten stanowi zatem teoretyczną refleksję na temat przemian jakości przeżywania "codzienności", czyli kategorii stylu życia na tle warunków społeczno-kulturowych opartych na indywidualizacji.

\section{Indywidualizacja jako trend współczesności}

Zawężenie pola problemowego, podjętego w niniejszym artykule, do kategorii indywidualizacji jako szczególnego atrybutu zachodzących przemian społecznych wymaga jego dookreślenia. Otóż, pojęcie indywidualizacji wyjaśnia specyficzny $\mathrm{w}$ dzisiejszych czasach rodzaj relacji pomiędzy jednostką a społeczeństwem, ściśle związanej ze zmianą struktur społecznych. Następujący sposób interpretacji indywidualizacji jest odmienny od tradycyjnego ujęcia opartego na dychotomii indywidualizm versus kolektywizm, reprezentowanego m.in. przez Janusza Reykowskiego. W tym podejściu analitycznym powiązaniem między jednostkami a społeczeństwem jest sieć funkcji pełnionych przed dane jednostki niejako w służbie społeczeństwu. Według J. Reykowskiego,

ujęcie indywidualistyczne zakłada, że świat społeczny to zbiór odrębnych indywiduów, samodzielnie starających się o znalezienie optymalnych dla siebie form i wa- 
runków życia (...) Człowiek definiuje samego siebie jako wyodrębnioną jednostkę, której tożsamość zasadza się na ostrym rozróżnieniu ja - inni ${ }^{1}$.

Dokonując charakterystyki pojęcia indywidualizm, J. Reykowski wymienia następujące wartości:

autonomia jednostki, niezależność emocjonalna, osobista inicjatywa, prywatność, wyraźna świadomość swojego ja (...). Jednostka sama odpowiada za siebie, sama określa co jest dla niej dobre lub złe, względnie w innej interpretacji, sama rozpoznaje dobro i $\mathrm{zło}^{2}$.

\section{Z kolei kolektywizm zakłada, że:}

jednostka nie jest bytem odrębnym, lecz częścią większej społecznej całości. Świat społeczny ujmowany jest jako układ stosunków między pewnymi społecznymi całościami. (...) Tożsamość jednostki ujmowana jest w kategoriach przynależności grupowej. Jej tożsamość społeczna odgrywa rolę decydującą w określaniu siebie samej, granice ja - my są nieostre, natomiast ostro zaznaczone są granice swój - obcy (my - oni) ${ }^{3}$.

Obie orientacje normatywne - indywidualizm i kolektywizm - stoją wobec siebie w opozycji, co wyklucza możliwość synkretycznego połączenia działań jednostkowych ze społecznymi, tak charakterystycznego dla współczesnych społeczeństw. Dlatego, paradygmat indywidualizm versus kolektywizm nie wpisuje się $w$ tok analiz podjętych $w$ niniejszym opracowaniu, bowiem nie uwzględnia kontekstu jakościowych przemian społeczno-kulturowych.

Wzajemna opozycja tendencji indywidualistycznych i kolektywistycznych jako możliwości odbioru świata społecznego straciła rację bytu w obecnych warunkach społeczno-kulturowych, opartych na pozornym odwrocie od wspólnotowości na rzecz rozwoju indywidualizacji. Współczesność niejako wymusza na jednostce synkretyczne łączenie obu tendencji uczestnictwo we wspólnocie dostarcza jednostce bodźców do namysłu nad własnym "Ja", co sprzyja ujawnianiu się postaw indywidualistycznych. Znakomitym przykładem niniejszego „wzorca mentalności jednostek we współczesnym świecie” 4 jest „etos demokratyczny” - kategoria wprowadzona do literatury przedmiotu przez Janusza Reykowskiego oraz uwypu-

${ }^{1}$ J. Reykowski, K. Skarżyńska, M. Ziółkowski (red.), Orientacje społeczne jako element mentalności, Poznań 1990, s. 17.

2 J. Reykowski, Kolektywizm i indywidualizm jako kategorie opisu zmian społecznych i mentalności, [w:] Indywidualizm a kolektywizm, red. K. Gawlikowski, Warszawa 1999, s. 25.

${ }^{3}$ J. Reykowski, K. Skarżyńska, M. Ziółkowski (red.), Orientacje społeczne, s. 18.

4 A. Cybal-Michalska, Tożsamość młodzieży w perspektywie globalnego świata, Poznań 2006, s. 234 . 
klona przez Agnieszkę Cybal-Michalską. Według autorki, „etos demokratyczny" opiera się na założeniu, iż:

pytanie o stosunek jednostki i grupy ujęty w kategoriach nadrzędności i podrzędności nie istnieje. Prawa i interesy jednostek są uzgadniane $\mathrm{z}$ prawami i dobrem zbiorowym. Towarzyszy temu dążenie do zachowania równowagi między jednostkowymi a społecznymi interesami 5 .

Era ponowoczesności w miejsce dymensji indywidualizm versus kolektywizm implikuje ich koegzystencję poprzez ukształtowanie $\mathrm{w}$ jednostkach pewnych cech osobowości, sprzyjających zasadzie synkretycznego łączenia tendencji wspólnotowych z osobowymi. Agnieszka Cybal-Michalska określiła je mianem „syndromu umysłowości prorozwojowej”, który

obejmuje zespół cech indywidualistycznych, stanowiących podstawę samorozwoju i samokształcenia jednostkowego (giętkość poznawcza, ciekawość poznawcza, poczucie sprawstwa, orientacja temporalna na przyszłość) oraz kolektywistycznych stanowiących podstawę harmonijnego współbycia z innymi ludźmi (ufność wobec innych i świata oraz poczucie godności i wzajemnego szacunku) ${ }^{6}$.

Zatem, czasy ponowoczesne wymuszają na jednostce konieczność elastycznego dostosowania się, zarówno do indywidualnych dążeń, jak też wspólnotowych potrzeb, co umożliwia adaptację do warunków wieloznaczności współczesności.

W nurt niniejszych analiz znakomicie wpisują się poglądy Ulricha Becka, osadzone na kanwie zaistniałych warunków społeczno-kulturowych. Według tego autora, indywidualizacja oznacza:

pełen historycznych sprzeczności proces uspołecznienia. (...) Tak rozumiana indywidualizacja nie oznacza także początku autokreacji świata ze zmartwychwstałych jednostek. Idzie ona raczej w parze $\mathrm{z}$ tendencjami do instytucjonalizacji i standaryzacji położeń życiowych. Uwolnione jednostki stają się zależne od rynku pracy, a przez to od wykształcenia, od konsumpcji, od społeczno-prawnych regulacji i zabezpieczeń, od planowania dróg i transportu, podaży dóbr konsumpcyjnych, możliwości i mód dotyczących poradnictwa i opieki w dziedzinie medycyny, psychologii i pedagogiki ${ }^{7}$.

Z powyższej definicji wynika wzajemne przeplatanie się tendencji do uspołeczniania oraz indywidualizacji, co pociąga za sobą szereg przeobrażeń w przeżywaniu codzienności przez jednostki egzystujące w ponowocze-

5 Tamże, s. 235.

${ }^{6}$ Tamże, s. 236.

${ }^{7}$ U. Beck, Społeczeństwo ryzyka. W drodze do innej nowoczesności, przekł. S. Cieśla, Warszawa 2002, s. 115. 
sności. Przede wszystkim, jak pisze U. Beck, czasy późnej nowoczesności ograniczają niezależność jednostek i ich poczucie kontroli nad biegiem zdarzeń życiowych.

$\mathrm{W}$ zaawansowanej nowoczesności indywidualizacja realizuje się $\mathrm{w}$ ramowych warunkach takiego procesu uspołecznienia, który w coraz większym stopniu uniemożliwia usamodzielnienie się: jednostka jest wprawdzie uwolniona od tradycyjnych więzi i źródeł zabezpieczenia bytu, musi za to wypełniać nakazy rynku pracy i wieść egzystencję konsumenta, podlegając odnośnym standaryzacjom i mechanizmom kontroli. Zamiast tradycyjnych więzi i form społecznych (klasa społeczna, rodzina nuklearna) występują wtórne instancje i instytucje, które wpływają na życiorys jednostki i czynią z niego wbrew indywidualnej dyspozycji, która urzeczywistnia się jako forma świadomości - igraszkę, mód, stosunków, koniunktur i rynków ${ }^{8}$ - wyjaśnia autor.

Zatem, indywidualizacja człowieka niejako realizuje się w ramach narzuconych form instytucjonalnego zniewolenia, co wbrew pozorom nie zawiera w sobie sprzeczności, bowiem jednostka w ponowoczesności ma zdolność umiejętnego łączenia obu tych tendencji.

Niniejszy fenomen wieloznaczności współczesności stanowi podstawową tezę pracy Zbyszko Melosika, zatytułowanej Kultura popularna i tożsamość młodzieży. Wniewoli władzy i wolności. Jak wyjaśnia autor:

współczesny człowiek, oczywiście także młody, żyje jednocześnie w dwóch rzeczywistościach. Pierwsza z nich działa na podstawie zasady wolności jednostki w kreowaniu własnej biografii, tożsamości oraz niekończących się (pozornie?) swobodnych wyborów dokonywanych na płaszczyźnie kultury popularnej i konsumpcji. Druga rzeczywistość działa jak gdyby odwrotnie: jej logika opiera się na potężnych regulatorach tożsamości i życia społecznego. (...) Mozaikowatości i fragmentaryczności sfery popkultury i konsumpcji towarzyszą przy tym nieuchronne rozproszenie i niejednoznaczność tożsamości. Jest to więc rzeczywistość, w której „wszystko zdaje się dozwolone", panuje w niej możliwość swobodnego nadawania znaczeń oraz daleko idącej indywidualizacji życia i codzienności. Jednocześnie jednak ten sam człowiek musi żyć w surowej rzeczywistości nakazów i zakazów (...) [gdzie - dop. P.P.D.] tożsamość jednostki jest adaptatywna i zdyscyplinowana, konformistyczna wobec narzuconych regul, a miejsca na własne interpretacje pozostaje bardzo niewiele ${ }^{9}$.

Dwoistość oraz sprzeczność współczesnych relacji pomiędzy jednostką a społeczeństwem dostrzegł również Sławomir Krzychała, podkreślając, iż:

${ }^{8}$ Tamże, s. 197.

${ }^{9}$ Z. Melosik, Kultura popularna i tożsamość młodzieży. W niewoli władzy i wolności, Kraków 2013, s. 10-11. 
emancypacja osoby staje się możliwa dzięki daleko posuniętej dyferencjacji funkcjonalnej nowoczesnego społeczeństwa. W konsekwencji jednostki w mniejszym stopniu zdane są tylko i wyłącznie na lokalne, stanowo-klasowe wspólnoty wsparcia, na zastane tradycyjne wzorce i przekazywane zwyczaje. Ich miejsce zajmują abstrakcyjne systemy społeczne, takie jak system opieki socjalnej i medycznej, system oświaty, system administracji i sądownictwa, prawnie uregulowany rynek pracy. (...) Emancypacja jednostki poprzez indywidualizację jest projektem tyleż obiecującym, co i zawodnym. Ryzyka (po?)nowoczesności mogą prowadzić do zaniku stabilności społecznej, aktywują nowe zależności, powodują nowe instancje standaryzacji doświadczeń społecznych. (...) Paradoks uzależnienia dynamiki indywidualizacji od (pół)nowoczesnych instytucji społeczno-politycznych staje się namacalnym doświadczeniem dnia codziennego. (...) Indywidualny przebieg życia poddany zostaje nowym mechanizmom kontroli i standaryzacji społecznej ${ }^{10}$.

Zatem, jak wynika z powyższych analiz, w świecie ponowoczesnym wolność samostanowienia oraz autokreacji własnego życia, będąca następstwem procesu wykorzenienia ${ }^{11}$, przeplata się z koniecznością dostosowania się do instytucjonalnych form życia społecznego. W ten sposób kreatywność w przeżywaniu własnego życia łączy się z jego standaryzacją.

Dokonując dalszej analizy znaczeniowej pojęcia indywidualizacja $w$ rozumieniu Ulricha Becka, należy wymienić za autorem jej wymiary ${ }^{12}$, które konstytuując się w zwartą całość, znakomicie wyjaśniają rolę i sens indywidualizacji $w$ nowoczesnym społeczeństwie. Pierwszy wymiar procesu indywidualizacji przejawia się we wzroście emancypacji społecznej, który w coraz większym stopniu uwalnia jednostkę od konieczności ścisłej przynależności do tradycyjnych struktur społecznych oraz identyfikacji, co prowadzi do intensyfikacji tendencji niezależnościowych $\mathrm{w}$ kwestii zupełnej samosterowalności własnym życiem. Kolejnym wymiarem procesu indywidualizacji jest zanik względnej stabilizacji społecznej, który wynika z utraty poczucia bezpieczeństwa ontologicznego $\mathrm{w}$ warunkach społeczno-kulturowych pozbawionych pewności, rutyny, przewidywalności ${ }^{13}$. Ostatni wymiar indywidualizacji odnosi się do procesu powstawania nowych zależności społecznych związanych z przemianami globalizacyjnymi, stawiającymi jednostkę $\mathrm{w}$ obliczu współczesnych zagrożeń oraz powiązań międzynarodowych, wynikających $\mathrm{z}$ bycia członkiem społeczeństwa ryzyka. Niniejsze wymiary procesu indywidualizacji ściśle wiążą jednostkę ze strukturami społecznymi wpisującymi się w logikę prawideł świata ponowoczesności, dlatego są one ujaw-

10 S. Krzychała, Ryzyko własnego życia. Indywidualizacja w późnej nowoczesności, Wrocław 2007, s. 94-95.

11 Patrz: Z. Bauman, Ponowoczesność jako źródto cierpień, Warszawa 2000.

12 Podaję za: S. Krzychała, Ryzyko wtasnego życia, s. 11-12.

13 Patrz: A. Giddens, Nowoczesność $i$ tożsamość. Ja i społeczeństwo w epoce późnej nowoczesności, przekł. A. Szulżycka, Warszawa 2010. 
niane zarówno na jednym, jak też na drugim poziomie. Indywidualizacja na poziomie zmiany struktury społecznej jest rekonstrukcją warunków życia oraz zasad funkcjonowania jednostek, dostosowaną do obecnie zaistniałego kontekstu społeczno-kulturowego. Z kolei, poziom zmiany subiektywnego podejścia do procesu indywidualizacji dotyczy przebudowy jednostkowych nastawień i przekonań wobec własnej osoby jako bytu konstytuującego własne życie. Przedstawiony powyżej sposób analizy kondycji współczesnego społeczeństwa jest często spotykany w literaturze przedmiotu, w której teoretycy ponowoczesności odwołują się do takich kategorii, jak: społeczeństwo jednostek $^{14}$, zindywidualizowane społeczeństwo ${ }^{15}$, jednostka poza społeczeństwem ${ }^{16}$.

Obraz współczesnych powiązań między jednostką a społeczeństwem byłby niepełny bez przedstawienia teorii opozycyjnych, głoszących schyłek indywidualizacji, przejawiający się w nowej jakości uczestnictwa we wspólnotach społecznych. Znakomitych wyjaśnień na tym obszarze naukowym dostarcza Michel Maffesoli17, głosząc teorię nowoplemion, która rzuca nowe światło na rozumienie procesu indywidualizacji w warunkach ponowoczesności. W myśl teorii Maffesolego, indywidualizacja we współczesnym systemie społecznym jest swoistym przyczynkiem do zajścia szeregu przemian, których konsekwencją jest wykształcenie się nowej jakościowo formy uspołecznienia jednostek poprzez bycie członkiem „nowych plemion”. Zatem, indywidualizacja człowieka ponowoczesności ujawnia się dzięki uczestnictwu w specyficznych formach wspólnotowości opartych na emocjonalnych więziach jej uczestników, co wymaga przestrzegania zasad dobrowolności oraz subiektywizmu. W ten sposób emocjonalna wspólnota „nowych plemion" oraz indywidualizacja są ściśle związane wzajemną dwustronną nicią przyczynowo-skutkową. Michel Maffesoli założył, że czasy ponowoczesności, sprzyjające tendencjom indywidualistycznym, interesownym kontaktom interpersonalnym, anonimowości ${ }^{18}$, wzbudzają w ludziach tęsknotę za uczestnictwem w grupach społecznych, w których indywidualność jednostki stanowi istotne ogniwo emocjonalnych relacji międzyosobniczych. Należy w tym miejscu podkreślić fakt, iż nie są to tradycyjne grupy społeczne utworzone na mocy przynależności klasowej o ściśle określonej, trwałej strukturze. Wspólnoty plemienne w znaczeniu nadanym im przez Maffesolego

\footnotetext{
${ }^{14}$ N. Elias, Społeczeństwo jednostek, przekł. J. Stawiński, Warszawa 2008.

${ }^{15}$ Z. Bauman, Zindywidualizowane społeczeństwo, przekł. O.W. Kubińscy, Gdańsk 2008.

${ }_{16}$ M. Gauchet, Nowy wiek osobowości. Próba psychologii wspótczesnej, Res Publica Nowa, 2002, 12, s. 40-51.

17 M. Maffesoli, Czas plemion: schyłek indywidualizmu w społeczeństwach ponowoczesnych, przekł. M. Bucholc, Warszawa 2008.

18 Patrz: Z. Bauman, Razem, osobno, przekł. T. Kunz, Kraków 2007.
} 
wyróżniają się od tradycyjnych wspólnot dobrowolnością uczestnictwa, brakiem zobowiązań do trwałej przynależności, wysokim stopniem rotacji uczestników oraz brakiem ich kontroli ze strony grupy społecznej. Zatem, nowe wspólnoty są tworzone na podstawie subiektywnego poczucia przynależności ich członków oraz grupowego przeżywania doznań emocjonalnych, które stanowią swoiste kryterium identyfikacji z daną zbiorowością nowowspólnotową. Jednostka odczuwa silne poczucie solidarności z grupą, co wbrew pozorom nie zatraca, a umacnia indywidualizm poprzez uzyskaną dzięki wspólnocie możliwość samorealizacji indywidualnej członków grupy. Innymi słowy, uczestnictwo w nowych plemionach wspomaga rozwój indywidualnych dążeń, będąc przestrzenią do jej ekspresji.

\section{Styl życia jako wolny wybór}

Kolejną, po indywidualizacji, kategorię analiz niniejszego opracowania stanowi pojęcie "styl życia”, będące przedmiotem zainteresowań wielu dyscyplin naukowych, podkreślających jego odmienne cechy konstytutywne. Ze względu na logikę narracji artykułu, nie zostanie podjęty dyskurs nad wszystkimi ujęciami stylu życia. Dokonana zostanie jedynie rekonstrukcja perspektyw teoretycznych, pozostających $\mathrm{w}$ bezpośrednim związku z tematem niniejszej publikacji.

Tradycyjne ujęcie kategorii stylu życia rozpatrywane było w kontekście pozycji społecznej jednostki w społeczeństwie, zatem odnosiło się do stratyfikacji społecznej jako kryterium różnicującego styl życia. W niniejszym podejściu styl życia rozumiany jest jako model funkcjonowania jednostki charakterystyczny dla danej grupy czy inaczej, posługując się terminologią „stratyfikacyjną" - klasy społecznej. Ów model funkcjonowania ma na celu manifestację własnej odrębności na tle innych grup społecznych, co ułatwia identyfikację z własną grupą odniesienia oraz zwiększa poczucie przynależności do niej. Przykładem tego typu definiowania pojęcia styl życia jest propozycja Andrzeja Sicińskiego, który ujmuje je jako:

zespół codziennych zachowań (sposób postępowania, aktywność życiowa), specyficzny dla danej zbiorowości lub jednostki (treść i konfiguracja owych zachowań); a inaczej mówiąc: charakterystyczny sposób bycia odróżniający daną zbiorowość lub jednostkę od innych ${ }^{19}$.

Jednym z czołowych przedstawicieli niniejszego podejścia jest niewątpliwie Pierre Bourdieu, którego poglądów nie sposób pominąć dokonując

${ }^{19}$ A. Siciński, Styl życia. Kultura. Wybór, Warszawa 2002, s. 22-23. 
analizy stylu życia w powiązaniu z przynależnością do określonej warstwy społecznej. W myśl tych założeń, istnieje widoczna kategoryzacja ujawnianego jednostkowego stylu życia zależna od partycypacji w danej klasie społecznej. Zatem, każda grupa społeczna posiada ściśle określony kod funkcjonowania, ujawniany $\mathrm{w}$ warstwie zarówno behawioralnej jak też poznawczej człowieka, który nie ulega hybrydyzacji. Stanowi on bowiem podstawowy wyznacznik identyfikacji z daną warstwą społeczną, tworząc tym samym źródło stratyfikacji społecznej.

Interesujących doniesień na temat zależności stylu życia od pochodzenia klasowego dostarcza przedstawiona przez Zbyszko Melosika koncepcja wszystkożerności/jednożerności, opracowana przez Richarda A. Petersona oraz Rogera M. Kerna ${ }^{20}$. W myśl niniejszej teorii, jednożerność to zjawisko dotyczące przedstawicieli klasy robotniczej, którzy hołdują zasadzie homologii społecznej, prowadząc ściśle określony styl życia, składający się z elementów dostarczanych przez kulturę popularną, odrzucając tym samym wszystko to, co wiąże się z kulturą wysoką. Z kolei, zwolennicy wszystkożerności to przedstawiciele klasy średniej prowadzący „wewnętrznie zróżnicowany styl życia", składający się zarówno z czynników dostarczanych przez kulturę popularną jak też wysoką. Są zatem otwarci na wszystkie propozycje kulturowe, nie zamykają się w sztywnych ramach danej kultury, ich styl życia stanowi swoistą „hybrydę kulturową”, będącą wynikiem indywidualnego, wolnego wyboru. Tego typu postawa jest zgodna ze wspólczesnymi trendami "patchworkowego stylu życia”, wolnego od wszystkiego co stałe, jednorodne, jasno określone i przede wszystkim zależne od pochodzenia klasowego.

Dzisiejsze warunki ponowoczesności oparte na elastyczności, zmianie, braku stałości i przewidywalności nie wpisują się w nurt myślenia o stylu życia jako kategorii ściśle zdeterminowanej przez czynniki zewnętrzne, chociażby takie jak przynależność klasowa. Do rozważań nad przemianami w codziennej egzystencji jednostek należy dopuścić jej subiektywny aspekt uwzględniający czynniki wewnętrzne, takie jak wolna wola czy wybór.

Niniejsza perspektywa rozumienia stylu życia jako efektu możliwości dokonywania wyboru i podejmowania indywidualnych decyzji została rozwinięta przez Andrzeja Sicińskiego w koncepcji "homo eligens” (człowieka wybierającego), w myśl której „styl życia jest przejawem pewnej zasady (zasad) wyboru wzorów codziennego postępowania spośród repertuaru zachowań możliwych $\mathrm{w}$ danej kulturze"21. Autor wyjaśnia zasadność swojej tezy, tłumacząc, iż

\footnotetext{
20 Podaję za: Z. Melosik, Kultura popularna, s. 37-38.

${ }^{21}$ A. Siciński, Styl życia, s. 78-79.
} 
zrozumienie zjawisk społecznych i psychologicznych jest niemożliwe bez spojrzenia na nie z punktu widzenia wyborów dokonywanych przez ludzi. Wyborów w takich lub innych sytuacjach codziennych i sytuacjach wyjątkowych, szczególnych, wyborów bardziej lub mniej świadomych, tak lub inaczej warunkowanych, dokonywanych z takiego lub innego repertuaru możliwości22.

Koncepcjami „homo”, wyjaśniającymi specyfikę jednostkowego funkcjonowania w aspekcie wielości praktykowanych stylów życia opartych na indywidualnym wyborze, są również „homo optionis”23 Ulricha Becka oraz „homo explorens" 24 Agaty Cudowskiej. "Homo optionis” to kategoria opisująca człowieka ponowoczesności egzystującego w czasach prymatu indywidualizmu, który musi permanentnie dokonywać wyborów kształtujących jego „projekt” życia. Z kolei, określenie „homo explorens” (człowiek poszukujący) uwypukla jednostkową konieczność bezustannego poszukiwania, dokonywania wyborów i podejmowania decyzji w sytuacji braku pewności co do ich słuszności.

Ideą spajającą kategorię stylu życia z indywidualnym wyborem jest koncepcja „kształtu życia” opracowana przez Bogdana Suchodolskiego, w myśl której „nie musimy żyć jak żyjemy, ale możemy własne życie kształtować” 25 . Zatem, pomimo determinacji życia ludzkiego od czynników niezależnych, pozostaje dużo przestrzeni, którą jednostka musi sama wypełnić swoimi wyborami, nadając tym samym życiu określony kształt. Tak więc, jak pisze Zygmunt Bauman: „życie jest dziełem sztuki, którego kształt nadaje sam artysta" ${ }^{26}$. Należy podkreślić specyficzne atrybuty kształtu życia różnicujące go od stylu życia. Jak tłumaczy Jan Szczepański:

kształt życia apeluje do istoty człowieczeństwa, nie tylko do indywidualnego czy społecznego modelu działań i zachowań, uwzględniającego wartości moralne i społeczne, akceptowane przez zbiorowości religijne. Kształt życia jest uosobieniem indywidualnej siły twórczej jednostki i jej zdolności do kontrolowania siebie. Życie osoby może przebiegać według ideałów moralnych lub religijnych, albo według wzorów narzuconych przez grupy odniesienia, albo przez ideały działań lansowane przez grupy zawodowe, albo także od indywidualnego postanowienia żyjącego człowieka. Taki kształt życia jest tworem autonomicznym indywidualności, niezależnej od nacisku grup społecznych, popędów biologicznych, modeli prawa i obyczaju oraz ideałów moralnych ${ }^{27}$.

22 Tamże, s. 81.

23 Patrz: U. Beck, Społeczeństwo ryzyka.

24 Patrz: A. Cudowska, Kształtowanie twórczych orientacji życiowych w procesie edukacji, Białystok 2004.

25 B. Suchodolski, Ksztatt życia, Warszawa 1982, s. 14.

${ }^{26}$ Z. Bauman, Sztuka życia, przekł. T. Kunz, Kraków 2009, s. 94.

${ }^{27}$ J. Szczepański, O Bogdana Suchodolskiego koncepcji ksztattu życia, [w:] Profesor Bogdan Suchodolski: jego filozofia, myśl pedagogiczna i działalność, red. I. Wojnar, H. Kwiatkowska, Z. Kwieciński, Warszawa 1996, s. 41. 
W sytuacji autonomicznej kreacji swojego życia, poprzez dokonywanie wyborów z różnorodnego repertuaru możliwości, jednostka staje się podmiotem odpowiedzialnym za swoje decyzje. Zatem, niezbędna staje się świadomość ponoszenia odpowiedzialności za własną egzystencję. Orientacja na odpowiedzialność stanowi według Agnieszki Cybal-Michalskiej istotny „element mentalności współczesnego społeczeństwa” ze względu na fakt, iz:

egzystencjalna sytuacja człowieka wymaga, aby jednostka kształtująca swoją biografię pod hasłem zrób to sam z elementów takich jak normy, wartości, preferowany styl życia, wierzenia religijne czy przekonania ideologiczne, które otrzymuje się dziś z wielu źródeł, brała i ponosiła pełną odpowiedzialność za swoje decyzje i wybory 28 - jak tłumaczy autorka.

W czasach prymatu relatywizmu moralnego oraz konieczności projektowania własnego życia, szczególnego znaczenia nabiera poczucie odpowiedzialności za swój los, co ponosi za sobą szereg konsekwencji dla kształtu jednostkowego stylu życia opartego na zasadzie wolnego wyboru pozbawionego determinizmu.

Powyżej poczynione ustalenia pozwalają stwierdzić, iż codzienna egzystencja jednostki składająca się na styl życia jest zależna od specyfiki zaistniałych warunków społeczno-kulturowych. Niniejszy wniosek potwierdza w swoich rozważaniach Mirosława Marody, tłumacząc, że:

jest zatem styl życia - o czym czasami się zapomina - pojęciem nierozerwalnie złączonym $\mathrm{z}$ rozwojem nowoczesnego społeczeństwa. Nie tylko ze względu na to, iż jednym $z$ jego elementów definicyjnych jest istnienie relatywnej swobody wyboru przez jednostki działań lokujących je w przestrzeni społecznej, a tym samym narzucających obserwatorowi ich identyfikację społeczną. (...) Także dlatego, iż jego pojawienie się $\mathrm{w}$ dyskursie socjologicznym związane jest w procesami społeczno-ekonomicznymi, w sposób zasadniczy zmieniającymi charakter współczesnych społeczeństw przemysłowych, co sprawia, iż różnią się one od tej klasycznej wersji nowoczesnego społeczeństwa kapitalistycznego, którą zazwyczaj przeciwstawia się społeczeństwom tradycyjnym² ${ }^{29}$.

\section{Konsumpcjonizm jako płaszczyzna wolnego wyboru w kreacji stylu życia}

Trendem współczesności, który szczególnie zmienia rys społeczeństw ponowoczesności, prowadząc do przemian w jakości codziennej egzystencji jednostek, jest niewątpliwie konsumpcjonizm. Niniejszy obszar ludzkiej ak-

${ }^{28}$ A. Cybal-Michalska, Tożsamość młodzieży, s. 71.

${ }^{29}$ M. Marody, Styl życia jako kategoria opisu socjologicznego, [w:] Wartości, praca, zakupy... O stylach życia Polaków, red. M. Falkowska, Warszawa 1997, s. 9. 
tywności stał się siłą wyznaczającą styl życia, osłabiając przy tym znaczenie przynależności klasowej. Konsumpcjonizm uwolnił jednostkę od sztywnych ram powinności i determinizmu oraz otworzył szerokie spektrum możliwości kreowania własnego stylu życia $\mathrm{z}$ bogatego wachlarza różnorodnych propozycji. To właśnie zjawisko konsumpcjonizmu pozwala ludziom łączyć się $\mathrm{w}$ grupy społeczne, których kryterium przynależności stanowi pewien wycinek aktywności konsumpcyjnej, pomijając istotność pochodzenia czy statusu ekonomicznego. $\mathrm{W}$ ten sposób jednostki egzystujące $\mathrm{w}$ ponowoczesności rezygnują z przynależności do grup subkulturowych posiadających jasno określone sztywne zasady uczestnictwa na rzecz zrzeszania się w "grupy lifestylowe" (Zbyszko Melosik), oparte na wspólnocie zainteresowań i sposobie spędzania czasu wolnego, cechujące się prymatem indywidualizmu, swobodą w ekspresji swojego "Ja" w ramach bycia członkiem owej grupy oraz odwrotem od narzuconych reguł funkcjonowania ${ }^{30}$. W tym miejscu po raz kolejny narzuca się konieczność przywołania wolnego wyboru jako kategorii dyferencjacji stylu życia, szczególnie w obszarze zachowań i preferencji konsumpcyjnych. Jak wyjaśnia Zbyszko Melosik:

tymczasowe afiliacje rzeczywiście pojawiają się $\mathrm{w}$ ramach punktów kulturowej konsumpcji, a w szczególności zatrzymań, jakie daje w tym zakresie kultura popularna w największym stopniu w muzyce, tańcu i sporcie. Mamy tutaj do czynienia z demokratyzacją stylów i praktyk - każdy może wybrać, co chce ${ }^{31}$.

Autor obrazowo przedstawia sytuację wyboru własnego stylu życia, odwołując się do symbolicznego wyboru pomiędzy ciasteczkiem brownie a cookie ${ }^{32}$. Zatem, odwołując się do rozważań Zbyszko Melosika:

styl życia w społeczeństwie konsumpcji opiera się na zasadzie: żadnych zasad, jedynie wybory; każdy może być każdym ${ }^{33}$, jednostka ma możliwość niejako horyzontalnego kreowania własnej tożsamości z dostępnych źródeł kulturowych - może się przemieszczać przez różnorodne płaszczyzny i wybierać komponenty (lub nawet gadżety) do kreacji swojej tożsamości i stylu życia ${ }^{34}$.

30 Patrz: Z. Melosik, Kultura popularna, s. 63.

31 Tamże, s. 77.

32 „Pamiętam sytuację, której przed laty byłem świadkiem w studenckiej restauracji na jednym z amerykańskich uniwersytetów. Studenci stali ze swoimi tacami, ze stygnącymi powoli potrawami, w długiej kolejce do kasy. Bezpośrednio przed dokonaniem zapłaty istniała jeszcze możliwość zakupu drobnych przekąsek przy kasie. I oto jedna ze studentek zatrzymała na ponad dziesięć minut rosnącą kolejkę, nie mogąc się zdecydować, czy na deser nabyć $\mathrm{w}$ tym miejscu ciasteczko typu brownie, czy cookie. Jej narastające wahanie nie wzbudzało żadnych emocji ani u kasjerki, ani u osób stojących za studentką - wszyscy bowiem zdawali sobie sprawę, że jej wybór jest istotny" - tamże, s. 78.

33 Tamże, s. 178.

34 Tamże, s. 319. 
Kategoria stylu życia powiązana jest również z temporalnym wymiarem jednostkowego funkcjonowania, czyli nastawieniem na konkretny wycinek czasowy zależny od aktualnych warunków społeczno-kulturowych. Jak podkreśla Elżbieta Tarkowska: „stosunek do czasu informuje o charakterze danej kultury, etosu czy stylu życia i o swoistych cechach tych całości" 35 . Współczesne warunki społeczno-kulturowe generują tendencję do nastawienia na teraźniejszość oraz „prymat natychmiastowości” (Zbyszko Melosik), co nie pozostaje bez wpływu na przemiany dotyczące kreowania jednostkowego stylu życia.

Prymat natychmiastowości i zmiany prowadzi do znaczących przekształceń w stylu życia współczesnych społeczeństw i w tożsamości młodzieży. Powstają styl życia typu instant i tożsamość instant, płynna i niestabilna - pop tożsamość. Typowa dla przeszłości potrzeba wewnętrznej harmonii przekształcona zostaje w ( niekiedy tylko neurotyczne) poszukiwanie nowości i wrażeń oraz zorientowanie na zintensyfikowaną przyjemność i natychmiastową gratyfikację $e^{36}$ - jak pisze Zbyszko Melosik.

Nastawienie temporalne niejako kształtuje określony styl życia, na co zwraca uwagę Elżbieta Tarkowska. Autorka tłumaczy, iż:

formowanie się określonych stylów życia, rozumianych jako całości społecznohistoryczne, to proces długotrwały. Wszystkie elementy składające się na określony styl życia, takie jak np. budżet czasu, wzory konsumpcji czy potrzeby kulturalne, zmieniły się w sposób zasadniczy w ciągu przedłużającego się kryzysu. W jaki sposób te zmiany doprowadzą do konfiguracji nowych stylów życia, trudno obecnie przewidzieć. Możemy jedynie mówić o trwałości lub zmienności pewnych elementów istotnych dla kształtu stylu życia, decydujących o jego odrębności. Do takich elementów należy zespół wartości wyrażających się w orientacjach temporalnych i w postawach wobec czasu jednostek, grup, zbiorowości. Zmiany w tej sferze zjawisk mogą być traktowane jako swojego rodzaju wskaźnik zasadniczych zmian zachodzących w tak złożonych całościach, jak styl życia, ethos, światopogląd37.

\section{Zakończenie}

Reasumując powyższe rozważania, należy jeszcze raz podkreślić zasadność analizy współczesnych przemian w sposobie kreacji własnego stylu życia na kanwie aktualnych warunków społeczno-kulturowych, opartych na zasadzie prymatu indywidualizacji. Specyfika czasów ponowoczesności sprawiła, iż realizowany styl życia stał się wynikiem wolnego wyboru,

\footnotetext{
${ }^{35}$ E. Tarkowska, Czas w życiu Polaków, Warszawa 1992, s. 32.

36 Z. Melosik, Kultura popularna, s. 170.

${ }^{37}$ E. Tarkowska, Czas w życiu Polaków, s. 32.
} 
uwalniając się tym sam ze sztywnych ram zależności od przynależności klasowej czy statusu społeczno-ekonomicznego. Styl życia w warunkach indywidualizacji, szczególnie na obszarze aktywności konsumpcyjnej, stał się efektem autonomicznego „zarządzania własnym życiem” 38 , tym samym czyniąc jednostkę „menadżerem własnego życia” 39.

\section{BIBLIOGRAFIA}

Bauman Z., Ponowoczesność jako źródło cierpień, Wydawnictwo Sic!, Warszawa 2000.

Bauman Z., Razem, osobno, przekł. T. Kunz, Wydawnictwo Literackie, Kraków 2007.

Bauman Z., Zindywidualizowane społeczeństwo, przekł. O.W. Kubińscy, Gdańskie Wydawnictwo Psychologiczne, Gdańsk 2008.

Bauman Z., Sztuka życia, przekł. T. Kunz, Wydawnictwo Literackie, Kraków 2009.

Beck U., Społeczeństwo ryzyka. W drodze do innej nowoczesności, przekł. S. Cieśla, Wydawnictwo Naukowe Scholar, Warszawa 2002.

Cudowska A., Kształtowanie twórczych orientacji życiowych w procesie edukacji, Wydawnictwo Trans Humana, Białystok 2004.

Cybal-Michalska A., Tożsamość młodzieży w perspektywie globalnego świata, Wydawnictwo Naukowe UAM, Poznań 2006.

Cybal-Michalska A., Młodzież akademicka a kariera zawodowa, Oficyna Wydawnicza Impuls, Kraków 2013.

Elias N., Społeczeństwo jednostek, przekł. J. Stawiński, Wydawnictwo Naukowe PWN, Warszawa 2008.

Gauchet M., Nowy wiek osobowości. Próba psychologii wspótczesnej, Res Publica Nowa, 2002, 12.

Giddens A., Nowoczesność $i$ tożsamość. Ja i społeczeństwo w epoce późnej nowoczesności, przekł. A. Szulżycka, Wydawnictwo Naukowe PWN, Warszawa 2010.

Krzychała S., Ryzyko własnego życia. Indywidualizacja w późnej nowoczesności, Wydawnictwo Naukowe DSWE TWP, Wrocław 2007.

Maffesoli M., Czas plemion: schyłek indywidualizmu w społeczeństwach ponowoczesnych, przekł. M. Bucholc, Wydawnictwo Naukowe PWN, Warszawa 2008.

Marody M., Styl życia jako kategoria opisu socjologicznego, [w:] Wartości, praca, zakupy... O stylach życia Polaków, red. M. Falkowska, Centrum Badań Opinii Społecznej, Warszawa 1997.

Melosik Z., Kultura popularna i tożsamość młodzieży. W niewoli władzy i wolności, Oficyna Wydawnicza Impuls, Kraków 2013.

Reykowski J., Kolektywizm i indywidualizm jako kategorie opisu zmian społecznych i mentalności, [w:] Indywidualizm a kolektywizm, red. K. Gawlikowski, Wydawnictwo IFiS PAN, Warszawa 1999.

Reykowski J., Skarżyńska K., Ziółkowski M. (red.) Orientacje społeczne jako element mentalności, Wydawnictwo Nakom, Poznań 1990.

${ }^{38}$ Inspiracją do użycia niniejszego terminu były rozważania A. Cybal-Michalskiej na temat kariery; A. Cybal-Michalska, Młodzież akademicka a kariera zawodowa, Kraków 2013.

39 Tamże. 
Siciński A., Styl życia. Kultura. Wybór, Wydawnictwo IFIS PAN, Warszawa 2002.

Suchodolski B., Ksztatt życia, Nasza Księgarnia, Warszawa 1982.

Szczepański J., O Bogdana Suchodolskiego koncepcji kształtu życia, [w:] Profesor Bogdan Suchodolski: jego filozofia, myśl pedagogiczna i dziatalność, red. I. Wojnar, H. Kwiatkowska, Z. Kwieciński, Wydawnictwo Edytor, Warszawa 1996.

Tarkowska E., Czas w życiu Polaków, PAN, IFiS, Warszawa 1992. 